\title{
THE MOSUL QUESTION AND THE TURKISH REPUBLIC: BEFORE AND AFTER THE FRONTIER TREATY, 1926
}

\author{
NEVIN ÇOSAR - SEVTAP DEMIRCI
}

\begin{abstract}
The Mosul Vilayet was part of the Ottoman Empire until the end of the First World War. Following the war it was occupied by Britain and the Vilayet became the bone of contention between the Ottoman Empire and Britain. After the War of Independence, the new Turkish Republic considered Mosul one of the crucial issues determined in the National Pact. Despite constant resistance, Britain managed to bring the issue into the international arena, scaling it down to a frontier problem between Turkey and Iraq. In the Turkish historical literature, the Mosul Question has been studied until the Frontier Treaty (1926). According to these studies, the Turkish government, in accordance with the exchange of letters annexed to the Frontier Treaty (1926), agreed to receive a fixed cash settlement of 500,000 pounds, rather than calculating the amount on a ten percent basis. That is to say, the Turkish government received the 500000 pounds and the folio of the Mosul Question was closed. But some findings proved that this was not the case. Some figures in the Turkish state budgets indicate that Turkey received payments on a ten percent basis instead of the fixed cash settlement. From 1931 to 1952 Turkey received royalty payments regularly. After 1952, two issues caused serious problems between Turkey and Iraq; namely, the unpaid years and insufficient payments. In latter period, Turkey chose to pursue a conciliatory policy and the issue was put aside for the purpose of establishing friendly relations with Iraq.
\end{abstract}

\section{KEYWORDS}

Mosul, Turkey, Iraq, Lausanne, Middle east, Oil. 


\section{Introduction}

Although a number of works concerning the pre-1926 period of the Mosul Question have been produced, no exhaustive attempt has been made to investigate the post- 1926 period. The primary aim of this study is to provide the historical background of the Mosul Question and to shed light on the aftermath of the Frontier Treaty of 1926. In order to obtain a fuller and truer picture of this important issue, we emphasize the developments, which took place in the post1926 period of the Mosul Question.

First, we examine the historical background of the Mosul Question, beginning from the Lausanne negotiations in which the fate of the Vilayet (province) became the key issue on the way to peace. Second, we investigate the period 1923-26 in which the increasing tension between Britain and Turkey dominated the League of Nations negotiations. Finally, we focus on the period after the 1926 Frontier Treaty, to clarify the payment questions of the Iraqi government's royalty revenues of ten percent to Turkey.

\section{The Lausanne Conference and the Mosul Question (1922- 1923)}

By the end of the First World War the Ottoman Empire had been defeated and was in a state of disintegration. The Mudros Armistice, which ended the war between the Ottoman Empire and the Allies in October 1918, was the final stage of this process and the Treaty of Sevres, which followed, confirmed it. However, the National Independence Movement, which emerged in Anatolia from the ruins of the Empire, rejected the proposed peace terms and set itself up as an alternative government based at Ankara. It drew up the National Pact, which set out the desiderata of the Nationalists, and it won a decisive victory over the Greeks, who invaded Anatolia in 1919. This military victory made a peace conference imperative and enabled the Turks to negotiate peace terms with the Allies on an equal footing. The peace treaty signed at Lausanne on 24 July 1923 
finalised the Turkish peace settlement, putting an end to the centuries-old Eastern Question. ${ }^{1}$

On the eve of the Lausanne Conference, the Eastern Question, the expression used to indicate the problems created by the decline and gradual dissolution of the Ottoman Empire, had been a focal point of European and British diplomacy for over a hundred years. ${ }^{2}$ The heartland of the Ottoman Empire and Asia Minor, including Istanbul, the Straits and Turkey-in-Europe beyond the capital, had been traditionally at the core of the Eastern Question. ${ }^{3}$

The root of the matter was the inability of the Ottoman Empire to maintain its territorial integrity. The more the economic and strategic interests of the Great Powers in the Empire grew and the more the ensuing rivalries became evident, the more firmly the Eastern Question became established as a priority on the agenda of international relations. Real peace and stability were further away than ever, since the decline of the Ottoman Empire opened up many possibilities of advantage to the many rival powers. Thus the Question, for a century and a half, remained the most lasting and intractable of all diplomatic issues. As Anderson argues, most of the major crises from 1856 to the outbreak of World War I in European politics were due to "a possible, a probable, or an actually threatening partition of the Ottoman territory." 4 The attempts of the Crimean War, the 1878 Congress of Berlin, and the Great War all illustrate the

${ }^{1}$ Sevtap Demirci, 'The Evaluation of Turco-British Diplomatic Strategies during the Lausanne Conference, 1922-1923.' Ph.D. Dissertation (London School of Economics and Political Science, Department of International History, 1988).

${ }^{2}$ Michael L. Dockril and G. J. Douglas, Peace Without Promise, Britain and the Peace Conferences, 1919-23 (London: 1981), p. 132.

${ }^{3}$ Ibid., p.181; also, see M. S. Anderson, The Eastern Question (London:1966); John Marriot, The Eastern Question: A Historical Study in European Diplomacy (Oxford: 1940); Gerald D. Clayton, Britain and the Eastern Question: Missolonghi to Gallipoli (London: 1971); M. E. Yapp. The Making of the Modern Near East, 1792-1923 (London: 1987), pp. 4797; Alan Palmer, The Decline and Fall of the Ottoman Empire (London: 1992).

${ }^{4}$ Harry Howard, The Partition of Turkey (New York: 1966), p.19. 
attempts of the different Powers to settle the Eastern Question. The Great War was but the culmination, so far as Turkey was concerned, of this long process of dissolution.

The end of the war witnessed not only the disappearance of the Ottoman Empire from the political arena, but also the emergence of Britain as the dominant power in the Middle East. Britain, as a victor with a vast amount of newly acquired territories, extended its commitments in Mesopotamia, the eastern Mediterranean, and India, all of which formed the key stones of the imperial strategic system following the war. Within this geographical area Turkey became of crucial importance to Britain as far as military, political and strategic factors were concerned. Britain could not afford to have Turkish affairs settled without its direct and active participation. Therefore, soon after the Armistice, Britain took the leading role in settling Turkish affairs. ${ }^{5}$

The traditional British policy towards the Ottoman Empire had been to maintain the independence and integrity of the Empire. Strategic concerns had been the prime motives behind the policy: the Straits, the route to India and the Persian Gulf, which Britain had long considered to be within its sphere of influence; Cyprus and the Suez Canal; and keeping Russia out of the Mediterranean to avoid a threat to Britain's eastern empire. The relations between the Ottoman Empire and Britain, which had been very close during the nineteenth century, began to cool somewhat towards the end of the century. The Ottoman Empire's participation in the First World War on the side of the Central Powers led Britain to reconsider completely its traditional policy. Britain's strategic interests in the Eastern Mediterranean could no longer be maintained by preserving and supporting the Ottoman Empire as the latter was now an enemy power. Britain consequently reversed its policy and sought the partition of the Ottoman Empire.

The Lausanne Conference was unique among post-war conferences in that it was the only one in which the Allies met the

\footnotetext{
${ }^{5}$ Soon after the Mudros Armistice was signed, Mosul Vilayet was illegally occupied by British troops.
} 
defeated enemy on anything like equal terms ${ }^{6}$ and which reflected an acceptance of the negotiating position of those whom the Allies considered the defeated Ottoman Empire that had signed the Sevres treaty, but was rather a new state which had fought for its independence and had not come to Lausanne as a supplicant. The Turkish delegates' aim at Lausanne was to add a diplomatic victory to the military victory which had been achieved in the field. Their standpoint was the Mudanya Armistice, whereas the Western Powers tended to rely on the Armistice of Mudros, which had been signed by the defeated Ottoman Empire.

In order to strengthen its negotiating position Turkey was, first of all, to rely on its military position. At almost every opportunity, Ismet Pasha, Head of Turkish Delegation, made it clear to the conference that he was not the representative of the defeated Ottoman Empire, but of victorious Turkey, which was determined to negotiate peace on equal terms. In addition to this, Turkey went to Lausanne to secure its prime objective: the National Pact, which came to represent the Nationalists' requirements and formed the basis of all negotiations with the Allied powers. The Nationalists proceeded to the Conference with a very definite programme: the complete scrapping of the Treaty of Sevres, a plebiscite for Western Thrace, the restoration of Mosul, the freedom of the Straits (provided that the independence of Turkey and the safety of Istanbul were ensured) no military restrictions, no minority provisions other than those in the European treaties, no financial and economic control, no capitulations, but the full sovereignty and independence of Turkey. In short, the National Pact in its entirety.

As for Britain, it aimed to restore its prestige in the East and in particular to ensure the freedom of the Straits; win Mosul for Iraq, which was under the British mandate; and drive a wedge between Ankara and Moscow. It has been argued that Curzon's (chief negotiator for Britain) handling of the Conference was a 'classical

${ }^{6}$ B.C. Busch, Mudros to Lausanne (Albany: State University of New York Press), p. 365; Richard T.B Langhorne, "The Treaty of Lausanne (1923) and the Recognition of Modern Turkey: The International Context.' Symposium on the Foreign Policy of Atatürk's Turkey (1923- 38), Proceedings (Istanbul: Bogazici University, 1984), p. 117. 
example of expert diplomacy. ${ }^{7}$ At the outset of the Conference, Curzon, having obtained control of the procedure, secured a victory over Ismet Pasha and was now in a position to conduct the negotiations in line with his own diplomatic strategy. He brought the questions in which Britain was primarily interested under discussions first and until he secured British interests in a satisfactory way- that is, an international regime of the Straits under British control and retention of the rich oil regions of Mosul- the Conference would slow down and progress stalled on issues concerning other parties. The most striking example of this strategy was seen over the Mosul Question, which lay at the heart of the British claims. The British were well aware that the Question of Mosul would constitute one of the principal obstacles to the establishment of peace in the Near East. Curzon was particularly cognizant of the fact that Mosul was going to be the crux of the conference. ${ }^{8}$ But it was only when he realized that negotiations had reached a deadlock that he initiated his strategy to slow down the conference and make the other issues difficult to settle.

Ankara's determination for peace with England was reiterated at every opportunity, and the necessity for reconciliation between England and Turkey was emphasized as an invaluable asset for peace. Although they had differences of opinion over the question of Mosul, Western Thrace and the Capitulations, which were seen as a gross violation of Turkish sovereignty, the Turkish attitude was conciliatory. Nevertheless, in spite of peaceful declarations there were also signs of extreme nervousness as to the question of Mosul. 'Mosul is Turkish and we want it back,' declared General Refet Pasha, a stalwart of the Nationalist movement. Recalling the unpleasant consequences of the former British government's policy, Refet Pasha was cautious. He tried to avoid provoking the new Cabinet and adopted a conciliatory attitude.

To avoid public disagreement in the conference and embarrassment before the international community, Britain and

\footnotetext{
${ }^{7}$ Harold Nicolson, Curzon, The Last Phase, 1919-1925 A Study on Post-War Diplomacy (New York: 1974), p. 282.

${ }^{8}$ FO839/16 No.229, January 241923 Curzon to Lindsay; F112/295, January 25,1923, Curzon to Balfour, Curzon Papers.
} 
Turkey agreed to keep the disputed points (namely Mosul) for private discussions. In the face of Ankara's demand for the restoration of Mosul to Turkey on ethnic, political, economic, historical, geographic, and military and strategic grounds, Britain was determined to settle this issue to its advantage. The Turks claimed the Vilayet of Mosul on several occasions and insisted that it was part of Turkish territory and each time the British replied that on such a basis, no further negotiations were possible. ${ }^{9}$ In the final stage of the negotiations, both sides managed to agree to keep the dispute out of the treaty and settle it through bilateral negotiations within nine months of the signature of the peace treaty.

\section{The Mosul Question between 1923 and 1926}

After the conference, the British position in Mesopotamia was perceived by the international community as a "colonial power" since the Iraqi-British territorial treaty had not been signed yet. It would take some time for Britain to establish its existence in Iraq and to establish a regime which would be in cooperation with it. The British, seeking to gain time, took a slow step towards the bilateral negotiations with the Turkish government.

When Ankara's initiative for talks reached London it became apparent that the Foreign Office was of the opinion that the only solution lay with the League of Nations. A report by the Foreign Office emphasized that it was Britain's responsibility towards the League of Nations to rescue the Arabs from the Turkish yoke and set up an independent Iraq. They had already signed an agreement with King Faisal to that end. The report also stated that the Mosul Question had nothing to do with oil resources. ${ }^{10}$ Despite the constant denial of British concern for Mosul oil, the Turkish Petroleum Company signed a concession agreement with the Iraqi government

\footnotetext{
${ }^{9}$ Bilal Simsir, Lozan Telgraflar $I_{2}$ No. 85. December 6, 1922, Ismet Pasha to Rauf Bey; No. 97 December 7, 1922, Ismet Pasha to Rauf Bey; No. 103. December 8, 1922 Ismet Pasha to Rauf Bey.

${ }^{10} \mathrm{FO} 371 / 10075$ E 1098/7/65, 29 January 1924, Brief Statement of the Origin of the Impending Negotiations about Mosul.
} 
on 14 March 1925 giving the company a seventy-five year concession on oil, before the fate of the Mosul Vilayet was determined. ${ }^{11}$

As agreed at Lausanne, the bilateral negotiations between Britain and Turkey over the Mosul Question started in Istanbul on 19 May 1924. The Golden Horn (Halic) Conference once again proved that the two sides were far from reaching an agreement and the negotiations were called off on 5 June 1924. Britain was anxious about the Turkish attitude after the breakdown of discussions. The question was whether Turkey would have full confidence in the League of Nations and take the case to the Council. Despite the fact that Turkey was more accommodating towards Britain, Ismet Pasha made it clear that Ankara would not take the issue to the League of Nations unless Britain ratified the Lausanne Treaty.

On 6 August 1924 Britain approached the League of Nations and asked that the Mosul Question be shelved in its political agenda. Britain put forward its economic, political, historical and strategic considerations and insisted that Iraq should retain Mosul. Ankara waged a diplomatic counter-offensive on August 25 in a note submitted to the League of Nations and emphasized that despite British intentions of dragging down the bilateral talks, Turkey did not oppose the dispute being referred to the League of Nations. Thus, the issue started to be discussed in the League on 20 Sept. 1924.

The dispute was shifted by Britain to the matter of fixing the Iraqi border. However, the Turks were adamant that the question mainly concerned the fate of the 'Mosul Vilayet' rather than the border issue. The League of Nations set up an inquiry commission consisting of three members influenced by Britain. ${ }^{12}$ Border dispute between Turkey and Britain led to military skirmishes. In the meantime, in order to avoid the increasing tension between two sides, Turkey applied to the League of Nations on 29 October 1924 for a temporary border to be fixed between Turkey and Iraq, which came to be known as 'the Brussels Line.' Britain relied on intelligence reports

\footnotetext{
${ }^{11}$ See footnote 18 .

${ }^{12}$ M.K. Oke, Musul ve Kurdistan Sorunu (Ankara: Turk Dunyasi Arastirmalari, 1992), p.148. See also, İhsan Şerif Kaymaz, Musul Sorunu, (İstanbul:Otopsi, 2003).
} 
emphasizing Turkish intentions of military operation. It would be naive to think that the Seyh Sait revolt in the Eastern part of Turkey was a coincidence. It remains controversial as to whether Britain encouraged the Kurdish uprising or not. Subsequent British intelligent reports revealed that Turkey had changed its position, that the Turkish Foreign Ministry was no longer in favour of a military operation, and that the Turkish government would accept the League of Nations' resolutions.

Considering the fact that Britain was the strongest member of the League and a permanent member of the Council and that Turkey was not even a member, it is not surprising that the commission unanimously reported that Iraq should retain Mosul and the Brussels line be made the permanent border. Turkey reluctantly had to accept the League of Nations' resolution and give up its territorial claims on the Vilayet of Mosul, but insisted that it should have a share in the Turkish Petroleum Company. This was rejected by London on the grounds that Turkey would receive a ten percent share from the royalties of the Iraqi government.

\section{Frontier Treaty and Mosul}

Britain managed to bring the issue into the international arena by scaling down it to a frontier problem. Afterwards, when the League of Nations Council appointed an investigative commission that recommended that Iraq should retain Mosul, the Ankara regime reluctantly assented to the decision in "Frontier Treaty: The United Kingdom and Iraq and Turkey." By signing the Frontier Treaty in 1926 with the Iraqi government, the Turkish government made the choice of peace, supported the independent Iraq, and sought to normalize the relations with Britain. ${ }^{13}$

The Frontier Treaty put an end to the land claims of Turkey. The frontier between Iraq and Turkey was drawn in 1926, as 'the temporary Brussels Line', which had been determined by the

\footnotetext{
${ }^{13}$ Tevfik Rustu, 'Speech on Frontier Treaty,' TBMM, Zabit Ceridesi, Vol. 26, no.II-3, 1926, p.65.
} 
commission of the League of Nations on 29 October 1924. There is only one article in the Treaty on the Mosul Question, Article 14.

According to the Frontier Treaty, Article 14 stipulates that the Iraqi government shall pay the Turkish government ten percent on all royalties it would receive over the following twenty-five years from the coming into force;

'1. from Turkish Petroleum Company under article 1 of its concession of the 14 March 1925;

2. from such companies or persons as may exploit oil under the provisions of Article 6 of the above-mentioned concession; ${ }^{14}$

3. from such subsidiary companies as may be constituted under the provisions of article 33 of the above-mentioned concession. ${ }^{15}$

In the literature of Turkish political history, it is known that the Turkish government, in accordance with the exchange of letters annexed to the treaty, agreed to receive a fixed cash settlement of 500,000 pounds, rather than calculating the amount on a ten percent basis. ${ }^{16}$ The question is whether the government received 500,000 pounds or ten percent of the royalties, which it was supposed to receive. In the literature, the Mosul Question has been studied until the Frontier Treaty. According to these studies, the Turkish

${ }^{14}$ Turkish Petroleum Company Concession with Iraqi government was signed on 14 March 1925. Article 10 is related to the determination of Iraqi Government's royalties. Article 6 defines reciprocal rights and selection of the plots. J.C.Hurewitz, Diplomacy in the Middle East, A Documentary Record 1914-1956 (Princeton: D. Van Notrand Co.Inc., 1956), p. 133.

${ }^{15}$ The Company shall be at liberty to form one or more subsidiary companies under its own control, for the working of this Convention, should it consider this to be necessary. Any such subsidiary company, shall, in respect of the area in which it operates, enjoy all the rights and privileges granted to the Company hereunder and assume all the engagements and responsibilities herein expressed, except the engagement, expressed in the first sentence of Article 32 hereof Hurewitz, Hurewitz, p. 141.

${ }^{16}$ Ismail Soysal, "Seventy Years of Turkish-Arab Relations and an Analysis of Turkish-Iraqi Relations (1920-1990)," Studies on Turkish-Arab Relations, Annual 6 (1991), p. 40; Mim Kemal Oke, A Chronology of the Mosul Question (1918-1926), (Istanbul: Turk Dunyası Arastırmaları Vakfı, 1991),p.75; Oral Sander, Siyasi Tarih (Ankara: İmge, 1989), p.70. 
government received the 500,000 pounds and the folio of the Mosul Question was closed. But some findings proved that this was not the case. Some figures in the Turkish state budgets indicate that Turkey received payments on a ten percent basis instead of the fixed cash settlement. In 1955, it was proved that the Turkish government had received some revenues from the Iraqi government on the ten percent plan. ${ }^{17}$

\section{Concession Agreements and Royalties of the Iraqi Government}

Governments in the Middle East receive two kinds of payments from oil companies, royalties and income taxes on profits. The royalties are usually taken in cash, though in Iraq and Iran the governments are entitled to take them in kind, meaning crude oil. ${ }^{18}$ The concession was granted by the Iraqi government to the Turkish Petroleum Company, on 14 March 1925 renamed the Iraq Petroleum Company (IPC). ${ }^{19}$ According to a new concession agreement during the twenty years following the completion of the pipeline to transport Iraqi oil to a port for export, $4 \mathrm{~s}$ (gold) royalty would be paid per ton crude "saved in field storage tanks or reservoirs"; after that period, the government's share would be raised or lowered in the same proportion as the profits made by the company during the previous five years had increased or decreased. ${ }^{20}$ The Iraq Petroleum Company became the major petroleum company in the region with the RedLine Agreement in Iraq. The company built the pipeline from Kirkuk

${ }^{17}$ Hikmet Ulugbay, Imparatorluktan Cumhuriyete Petropolitik (Ankara:Ayraç Yayınevi,2003); Nevin Cosar, 'Musul Petrollerinden Turkiye Butcesine Gelen Paralar' Toplumsal Tarih 2 (1997), Baskın Oran, Musul Sorunu Misakı Milli ve Ahlak, Radikal, 12 Jan. 2003.

${ }^{18}$ Wayne. A. Leeman, Price of Middle East Oil, An Essay in Political Economy (New York: Cornell University Press, 1962), p.185

${ }^{19}$ The concession of the Iraq Petroleum Company started from 14 March 1925 and expired in 2000. Ownership: British Petroleum, Royal DutchShell Group, Near East Development Corp. Compagnie Française des Petroles each hold $23.75 \%$, Participations and Explorations Corp (C.S. Gulbenkian Estate) has $5 \%$ of the company.

${ }^{20} \mathrm{C}$. Issawi and M. Yeganeh, The Economics of Middle Eastern Oil (New York: Preager, 1962), p. 128. 
to Haditha, which branched off in two directions, one line going to Haifa (Palestine) and another to Tripoli (Lebanon). ${ }^{21}$ In 1931, with the revised agreement of 1925 , until the commencement of export the Iraq Petroleum Company was to pay the government the sum of 400,000 pounds (gold) annually. ${ }^{22}$ The Iraqis were dissatisfied with the royalties they were receiving. Difficulties developed when the company's second payment fell due in January 1932, as the British pound went off the gold standard. Iraq was paid 578,000 pounds instead of the 400,000 pounds (approx.) provided by the new agreement signed in $1932 .{ }^{23}$ Ten percent royalty payments to Turkey also began with the IPC's payments to Iraqi government in 1931.

\section{The Beginning of Payments to Turkey}

Turkish-Iraqi relations were dominated by the Mosul Question until the Frontier Treaty. Iraq was a mandate of Britain until 1930, when the Iraqi-British Treaty opened the way to an independent Iraq. The Iraqi government wanted to extend and normalize its foreign relations; Turkey was one of countries with which it sought to do so. In fact, relations far more cordial than could have been expected were maintained with the Turkish Republic. The feasible reestablishment of social contacts restored many friendships and offered much common ground; nor, once the settlement of 1926 was accepted loyally, was there any clash of interests. ${ }^{24}$ There was a shadow of the Mosul Question on the commencement of relations between Iraq and Turkey, but not much negative influence was observed. Turkish foreign policy was based on respecting the sovereign rights of its neighbour countries.

${ }^{21}$ With the pipeline completed in 1934 , oil production increased, but not as much as the Iraqi government had anticipated. B. Swadran, The Middle East Oil and the Great Powers (New York: John Wiley and Sons, 1973), p. 243.

${ }^{22}$ Ibid., p. 238.

${ }^{23}$ Ibid., p. 245.

${ }^{24}$ S.H. Longrigg, Iraq 1900 to 1950, A Political, Social, and Economic History (London:Oxford Univ. Press, 1953), p. 215. 
After the 1926 Treaty, relations between Turkey and Iraq gradually started to improve. In 1928, each side opened legations in the other's capitals and both countries presented their credentials. King Faisal and his ministers made a state visit to the Turkish capital in July 1931, and early in 1932, The Turco-Iraqi Treaties of Residence, Commerce, and Extradition was signed. Although, The Treaty of Bilateral Commerce and Friendship was signed between the Turkish and Iraqi governments in 1932, it was not approved by Britain, which shows the continuation of British control over Iraqi foreign policy after the mandate. In 1937, a non-aggression Treaty was signed with Iraq, called the Saadabat Pact. ${ }^{25}$

During King Faisal's visit the first payment was made to Turkey by the Iraqi government as ten percent of the 400,000 pounds in 1931. The Turkish Ambassador to Iraq, Tahir Lütfi, reported that when the Iraqi government received 400,000 pounds, ten percent of this amount was sent to Turkey. ${ }^{26}$

The Turkish state budget figures prove that Turkey received the royalty payments on a ten percent basis. Table 1 shows the Royalty Payments of the Iraqi Government and the amounts that Turkey received in the state budgets. ${ }^{27}$ The first column shows the Iraqi government's royalties; the second column ten percent of the royalties; the third ten percent of the royalties in Turkish Lira; and the last two columns show the estimated and realized budget revenues of Turkish budgets to which payments were made by the Iraqi government.

${ }^{25}$ The Saadabad Pact was signed by Iran, Iraq, Turkey and Afghanistan and was primarily concerned with "non-intervention," the "inviolability of frontiers," "non-aggression," "consultation on international problems," "good neighbourliness relations and respect for the League of Nations charter and world peace." It was not a defence or military pact. Soysal, p.39.

${ }^{26}$ Cumhuriyet, 16 July 1931.

${ }^{27}$ For another calculation see, İlhan Uzgel, and Omer Kurkcuoglu, "Bat1 Avrupa'yla Iliskiler," in Turk Dis Politikast, (ed.) Baskın Oran, (Istanbul: İletisim, 2002), p.270. 
Table 1

Iraqi Government Royalties and Payments to Turkish Budgets

\begin{tabular}{|c|c|c|c|c|c|}
\hline & $\begin{array}{c}\text { Iraqi } \\
\text { Government } \\
\text { Royalties }\end{array}$ & \multicolumn{2}{|l|}{ Calculated \% 10 Royalties } & \multicolumn{2}{|c|}{$\begin{array}{c}\text { Payments to Turkish Budgets } \\
\text { (TL) }\end{array}$} \\
\hline Years & Pounds & Pounds & Turkish Lira & Estimated & Realized \\
\hline 1931 & 401.400 & 40.140 & 387.752 & 2.000 .000 & 3.126 .000 \\
\hline 1932 & 579.400 & 57.940 & 429.335 & 450.000 & 1.711 .682 \\
\hline 1933 & 742.971 & 74.297 & 521.566 & 518.000 & 617.469 \\
\hline 1934 & 1.484 .126 & 148.413 & 945.388 & 500.000 & 682.304 \\
\hline 1935 & 1.009 .400 & 100.940 & 622.800 & 500.000 & 596.818 \\
\hline 1936 & 1.049 .833 & 104.983 & 656.146 & 800.000 & 618.212 \\
\hline 1937 & 1.251 .592 & 125.159 & 780.993 & 800.000 & 714.990 \\
\hline 1938 & 1.896 .533 & 189.653 & 1.168 .264 & 800.000 & 1.065 .416 \\
\hline 1939 & 2.230 .146 & 223.015 & 1.264 .496 & 1.100 .000 & 919.807 \\
\hline 1940 & 1.786 .941 & 178.694 & 934.572 & 1.000 .000 & 687.261 \\
\hline 1941 & 1.380 .541 & 138.054 & 722.021 & 700.000 & 619.362 \\
\hline 1942 & 1.763 .061 & 176.306 & 922.076 & 620.000 & 621.735 \\
\hline 1943 & 2.209 .161 & 220.916 & 1.153 .181 & 620.000 & 808.161 \\
\hline 1944 & 2.451 .644 & 245.164 & 1.318 .012 & 750.000 & 1.033 .522 \\
\hline 1945 & 2.664 .147 & 266.415 & - & & - \\
\hline 1946 & 2.724 .092 & 272.409 & 1.834 .751 & 1.000 .000 & 1.108 .777 \\
\hline 1947 & 2.705 .143 & 270.514 & 3.064 .925 & 2.250 .000 & 2.452 .932 \\
\hline 1948 & 2.137 .781 & 213.778 & 2.432 .800 & 2.450 .000 & 2.430 .750 \\
\hline 1949 & 3.126 .316 & 312.632 & 3.188 .851 & 2.450 .000 & 1.277 .320 \\
\hline 1950 & 6.781 .583 & 678.158 & 5.337 .105 & 1.500 .000 & 2.138 .066 \\
\hline 1951 & 15.100 .000 & 1.510 .000 & 11.883 .697 & 2.200 .000 & 3.910 .729 \\
\hline 1952 & 40.600 .000 & 4.060 .000 & - & 6.000 .000 & - \\
\hline 1953 & 58.300 .000 & 5.830 .000 & - & 35.000 .000 & - \\
\hline 1954 & 68.400 .000 & 6.840 .000 & 53.625 .588 & 75.000 .000 & 4.055 .490 \\
\hline 1955 & 73.700 .000 & 7.370 .000 & 0 & 100.000 .000 & - \\
\hline & & & & 1962 & \\
\hline
\end{tabular}

Sources: Mikdasha, 1966, p.106; Issawi and Yeganeh, 1962, p.183; Maliye ve Gumruk Bakanlıgı (Ministry of Finance, Budgetary Accounts) Genel Butçe Kanunları, Cilt 1, Ankara, 1992; Maliye ve Gumruk Bakanlıgı (Ministry of Finance, Realized Budgetary Accounts), Kesin Hesap Kanunları, 19311955, Ankara. 
Until 1934, these payments were registered in the Turkish budgets under the heading 'extra ordinary revenues.' For this reason, the figures of 1931 and 1932 contain some other revenues. In 1934, a new account was opened in order to register the revenue under the title of 'Revenues from Mosul Petroleum'. The royalty payments to Turkey fluctuated each year with respect to the oil production in Iraq. Table 1 shows that there is a difference between the percentages of royalty payments and the amounts paid to Turkey. Due to a lack of data, we are unable to ascertain how the Iraqi government made the calculations for the payments. But this difference may have come from the fact that the royalties paid to the Iraqi government were gross figures and included tax commutation payments, inspection fees and scholarships to Iraqi students. ${ }^{28}$

\section{Change in Concession Agreements and Payment Problems}

In the period 1934 to 1950 , the major element of revenue was tonnage royalty from the IPC's concession, paid at the rate of $4 \mathrm{~s}$ (gold). In Iraq, the pipelines constituted a bottleneck. The construction of new pipelines was started in 1946, but owing to political and material difficulties it was not until 1949 that the volume of oil flowing to the Mediterranean increased. ${ }^{29}$ So the amounts paid to Turkey stood at a low level. The flow of oil through Haifa stopped in April 1948. With the increase in domestic prices and the price of petroleum, the share of the governments in the value of the oil produced declined since payments to the governments were made on a fixed basis. In Iraq, the royalty rate was increased from $4 \mathrm{~s}$ (gold) to $6 s$ (gold) a ton, or about 33 cents a barrel in August 1950.30 Royalties rose from about one million pounds in 1935 to 6.8 million pounds in 1950. This was concomitant with an increase in oil exports from 3.6 to 6.2 million tons, as well as with an increase in the value of gold in terms of sterling. ${ }^{31}$ The fifty-fifty method of payment was utilized

${ }^{28} \mathrm{Z}$. Mikdashi, A Financial Analysis of Middle East on Oil Concessions: 1901-1965 (New York: Praeger, 1966), p.106.

${ }^{29}$ Issawi and Yeganeh, p. 132.

${ }^{30}$ Ibid., p. 134.

${ }^{31}$ Mikdashi, p. 105. 
with the agreement signed in 1952. These developments increased oil production and the royalties of the Iraqi government.

Table 1 shows that the ten percent royalty payments to Turkey were made regularly until 1952 by the Iraqi government, except the year 1945. In 1952, payments were stopped, which brought a new question regarding the determination of the starting year of the payments. The Iraqi government calculated it from 1926, the Turkish government, from 1931. The Iraqi government thus ceased its payments in 1952 twenty-five years after the agreement went into force. The Turkish government protested that since the production of petroleum at Kirkuk had started only in 1931, and Turkey's share had been paid only since that date, the 25 -year period should not come to an end until 1955, which had also been accepted in various bilateral agreements between Turkey and Iraq.

Another point of contention was that after 1950, -Turkey received payments according to the previous agreement while the Iraqi government received payments according to the new agreements $(1950,1952)$. Turkey wanted new arrangements with respect to the new oil agreements. In 1952, one bureaucrat from the Ministry of Finance was sent to Iraq in order to find out the changes in the payments of ten percent with respect to the new concession agreement. ${ }^{32}$ The problem was defined by the bureaucrats of both countries and a solution was found for the unpaid years. Some negotiations were took place on this subject in Ankara. But, under the new political and economic conditions of the Middle East, the Turkish government had not been taken into consideration and not received much attention on this subject.

The final payment was made in 1954 by the Iraqi government, but the payment was lower than it was estimated in the Turkish Budget. Iraq refused to concede to Turkey what was in fact its right and when at this time preparations started to be made for the Baghdad Pact, which was to be concluded in 1955, the Turkish government

${ }^{32}$ The Turkish bureaucrat Cahit Kayra revealed that the registration of the accounts on the Mosul payments were a mess in both countries. Cahit Kayra, 38 Kusagı, (İstanbul: Is Bankası, 2001), pp.145-51. 
saw fit not to insist on it. ${ }^{33}$ Indeed, the Turkish governments continued to put this item (Revenues from Mosul Petroleum) into its annual budgetary calculations and forecasts right up to 1958. From 1959 to 1986, this item was kept in the Turkish budgets in accounts receivable. Turkey showed that these payments from Iraq had not been forgotten. In 1986, Prime Minister Turgut Ozal removed this item from the budget as a part of improving Turko-Iraqi relations.

\section{Conclusion}

To sum up, the Mosul Vilayet was part of the Ottoman Empire until it came under the British occupation in 1918 following the First World War. After the War of Independence, the new Turkish Republic considered Mosul one of the crucial issues determined in the National Pact. British foreign policy conducted according to the British economic interests in the Middle East, eventually shaped the fate of the region. Despite constant resistance, Britain managed to bring the issue into the international arena, scaling it down to a frontier problem between Turkey and Iraq. In the Frontier Treaty of 1926, Turkey received ten percent of the Iraqi government's royalty payments for twenty-five years. From 1931 to 1952 Turkey received royalty payments regularly. There were two problems, first, the unpaid years, as noted in Table 1, and insufficient payments regarding the calculations of the ten percent of the royalties of the Iraqi government after the new concession agreements.

Turkey did not create an international issue about this problem. There were unpaid years, when Turkey did not receive these payments. Since then, some assertions have been made in the Turkish media that Turkey has not received its share of the Mosul petroleum, that it should receive much more payments from the share of the Iraqi government's royalties. Turkey, however, has not pursued the issue in the interest of foreign policy towards its neighbouring countries and shut down the folio.

\footnotetext{
${ }^{33}$ The Baghdad Pact was set up between Turkey, Iraq, Iran, Pakistan, and the United Kingdom in 1955.
} 